\title{
PEMANFAATAN VIDEO UNTUK MENINGKATKAN AKTIFITAS DAN HASIL BELAJAR MATERI DAKWAH RASULULLAH SISWA SMK
}

\author{
Fithriyanti \\ SMK SMTI Pontianak \\ Email: fullhope11@gmail.com
}

\begin{abstract}
This research aims to increase the activity and learning outcomes of students on material proselytizing of the prophet in the class XF SMK SMTI Pontianak. This research consist of 2 (two) cycles with each meeting takes time $3 \times 45$ minutes. Each cycle consisted of planning, implementation, observation, and analysis section.To know classmanagement, teacher and student; s observation sheet was used. The results showed that using of video that can improve the activity and student learning outcomes on material proselytizing of the prophet in class XF SMK SMTI Pontianak. It can be seen from the increase in average grade from 70 to 72.82 and the percentage of students who pass the tes rosefrom $56.52 \%$ in the first cycle becomes $82.61 \%$ in the second cycle.
\end{abstract}

Keyword: Video, Learning Outcomes, Da'wah Rasulullah SAW

\section{PENDAHULUAN}

Proses pembelajaran merupakan sebuah proses komunikasi antara guru dengan siswa melalui bahasa verbalis sebagai media primer dalam penyampaian materi pelajaran (Wina Sanjaya, 2011:2). Namun demikian, tidak berarti proses komunikasi tersebut terjadi selalu melalui bahasa verbal, dibutuhkan juga media lain untuk menyampaikan materi pelajaran agar siswa mudah memahami materi. Maka dari itu dibutuhkan media yang tepat untuk membantu menyampaikan informasi-informasi yang tidak dapat terwakilkan dengan bahasa verbal saja. Menurut Rudi Susilana dan Cepi Riyana (2008:4), Media merupakan bagian dari proses komunikasi. Salah satu media yang dinilai dapat membantu dalam proses belajar mengajar yaitu dengan menggunakan video. Dengan media video, siswa akan terbantu dalam memahami konsep-konsep yang tidak dapat terwakilkan dengan melalui verbal saja.

Media video dirasa cocok digunakan untuk membantu menggambarkan situasi dan kondisi strategi dakwah Rasulullah saw. periode Madinah agar mudah memahami materi tersebut. Dengan bantuan media video siswa akan terbantu memahami substansi dan strategi dakwah Rasulullah saw. periode Madinah. Dan diharapkan dapat meningkatkan hasil belajarnya menjadi lebih baik, sehingga dapat mencapai nilai kriteria ketuntasan minimum (KKM) yang telah ditetapkan sekolah yaitu 75 dengan presentase pencapaian KKM sebesar 70\%.Standar kriteria ketuntasan minimal (KKM) yang diterapkan di SMK-SMTI Pontianak khususnya mata pelajaran Agama Islam adalah 75.

Dalam rangka mencapai ketuntasan yang distandarkan tersebut, pelaksanaan proses pembelajaran harus dilaksanakan dengan melibatkan keterlibatan mental dan kerja siswa sendiri. Metode ceramah yang digunakan guru dalam proses pembelajaran selama ini cenderung menyebabkan proses pembelajaran kurang kondusif. siswa banyak yang kurang memperhatikan dan kurang termotivasi sehingga hasil belajar yang diperoleh juga kurang memuaskan.

Dari 23 siswa yang mengikuti mata pelajaran Agama Islam, yang melampaui KKM (tuntas) hanya sekitar $47,82 \%$ dengan nilai rata-rata kelas 70. Sedangkan sisanya belum mencapai KKM yang distandarkan. Hal inilah yang menyebabkan sangat perlu untuk dilakukan sebuah penelitian lebih lanjut dalam rangka meningkatkan motivasi dan hasil belajar siswa. 


Tabel 1. Hasil Belajar Siswa XF SMK SMTI
Pontianak Pada Materi Dakwah Rasulullah
\begin{tabular}{|ccccc}
\hline No & Kelas & $\begin{array}{c}\text { Jumlah } \\
\text { Siswa }\end{array}$ & Tuntas & $\begin{array}{c}\text { Tidak } \\
\text { Tuntas }\end{array}$ \\
\hline 1 & XE & 23 & 15 & 8 \\
\hline 2 & XF & 23 & 11 & 12 \\
\hline 3 & XG & 25 & 18 & 7 \\
\hline 4 & XH & 22 & 14 & 8 \\
\hline
\end{tabular}

(Sumber : Data Kurikulum SMK SMTI Pontianak

Tahun Pelajaran 2017/2018)

Menurut data yang dapat dilihat pada Tabel 1 dapat dilihat bahwa perolehan hasil belajar siswa pada materi sebelumnya yaitu materi Dakwah Rasulullah periode Mekah menunjukan bahwa kelas XF merupakan kelas yang memiliki hasil akademik yang memiliki jumlah tidak tuntas paling banyak dibanding kelas lainnya di SMK SMTI Pontianak, selain itu keaktifan belum maksimal terfokus pada pembelajaran sehingga terkesan kelas agak ribut. Berdasarkan data ini kemudian guru mencoba melakukan penelitian tindakan kelas dengan menggunakan media audio visual (video) untuk meningkatkan hasil belajar siswa kelas XF SMK SMTI Pontianak. Terdapat banyak penelitian tindakan kelas yang menggunakan media dan digunakan oleh guru sebagai rujukan. Beberapa penelitian tindakan kelas tersebut antara lain: a) "Penggunaan Media Pembelajaran Video Untuk Meningkatkan Hasil Belajar Biologi Siswa Pada Konsep Sistem Reproduksi Manusia di SMAN 6 Tangerang Selatan”.

Penelitian ini dilakukan oleh Bayuda Luqman Al-Farisi \& Nengsih Juanengsih, M.Pd dari Program studi Pendidikan Biologi Universitas Islam Negeri Jakarta tahun 2014. Kesimpulan dari penelitian tersebut adalah terjadi peningkatan hasil belajar (kognitif) siswa kelas XI IPA1 SMAN 6 Tangerang Selatan tahun Pelajaran 2013/2014 dengan jumlah siswa sebanyak 36 pada konsep sistem reproduksi manusia dengan penggunaan media video. b) Pemanfaatan Video sebagai Media Pembelajaran Matematika SD/MI. Penelitian ini dilakukan oleh Hamdan Husein Batubara dan Dessy Noor Ariani dari Prodi Pendidikan Guru Madrasah Ibtidaiyah Universitas Islam Kalimantan MAB, Banjarmasin Tahun 2016. Kesimpulan dari penelitian ini adalah penggunaan video untuk pembelajaran matematika di sekolah dasar dibagi menjadi 4 macam, yaitu: video presentasi linier, video tutorial, rekaman video, dan klip video lagumatika dengan lirik. Keunggulan video sebagai media pembelajaran mudah digunakan dan mampu menjelaskan konten dengan lebih nyata. Kelemahannya tidak interaktif.

Hasil belajar yang dianalisis dalam penelitian ini perubahan nilai tes siklus I dan skilus II. Materi yang diajarkan pada penelitian ini : Strategi dakwah Rasulullah saw periode Mekah dan Strategi dakwah Rasulullah saw periode Madinah. Penggunaan media video lebih menekankan pada konsentrasi siswa dalam memperhatikan alur cerita serta tokoh dari video tersebut.

\section{METODE PENELITIAN}

Penelitian Tindakan Kelas (PTK) ini dilaksanakan di SMK SMTI Pontianak dengan fokus penelitian hasil belajar siswa kelas XF SMK SMTI Pontianak pada materi Strategi dakwah Rasulullah saw periode Madinah. Populasi siswa kelas XF SMK SMTI Pontianak yang diteliti berjumlah 23 siswa. Penelitian tindakan kelas ini diadakan pada semester genap tahun pelajaran 2017/2018. Penelitian Tindakan Kelas (PTK) ini dilaksanakan dalam 2 (dua) siklus dengan masing masing siklus terdiri dari 1 (satu) pertemuan dengan 3 jam pelajaran dan tes siklus dilaksanakan pada pertemuan berikutnya. Setiap pertemuan dilakukan untuk melihat dan memperbaiki proses pembelajaran menggunakan media video dengan setting pelaksanaan penelitian di ruang kelas SMK SMTI Pontianak.

Sumber data penelitian ini berasal dari siswa kelas XF SMK SMTI Pontianak, guru peneliti, dan observer. Terdapat dua jenis data, yaitu data kuantitatif berupa nilai tes setiap siklusnya, dan data kualitatif berupa kalimat yang dapat menggambarkan proses belajar mengajar. Untuk keperluan analisis, dilakukan tes tulis, lembar observasi, kuesioner, dan dokumentasi.

Penelitian tindakan kelas ini dilaksanakan dalam 2 siklus dengan 2 kali pertemuan.Tiap pertemuan didesain sesuai dengan kondisi dan dengan tujuan yang ingin dicapai. Penelitian tindakan kelas ini terdiri dari 1) Siklus 1 yang terdiri dari refleksi awal, perencanaan tindakan, pelaksanaan tindakan, observasi tindakan, dan refleksi tindakan. Kriteria ketuntasan pada siklus I adalah 55\% siswa mencapai $\mathrm{KKM}=75$; 2) Siklus 
II terdiri dari perencanaan tindakan pelaksanaan tindakan, observasi tindakan,dan refleksi tindakan. Kriteria ketuntasan pada siklus II adalah $75 \%$ siswa mencapai $\mathrm{KKM}=70$; dan 3) Kegiatan Akhir yang terdiri dari a) Menulis angket (kuesioner) pendapat siswa; b) Membuat analisa hasil penelitian dan pembahasan penelitian.

Tiap kegiatan kemudian dijelaskan lebih mendalam sebagai berikut 1) Refleksi awal: Pada refleksi awal guru mengidentifikasi kesulitan siswa kelas XF dalam memahami materi strategi dakwah Rasulullah saw dengan memberikan tugas membaca materi, kemudian memberikan beberapa soal untuk dianalisa kesulitan yang dialami siswa. 2) Perencanaan Tindakan: Guru peneliti menyusun Rencana Pelaksanaan Pembelajaran yang sesuai dengan menggunakan media audio visual (video) dan analisis kondisi siswa pada tahap pendahuluan, membuat lembar observasi kegiatan guru dan siswa, membuat lembar kerja siswa, membuat soal tes penempatan, tes formatif dan tes siklus, menyiapkan buku sumber dan media pembelajaran, serta menyusun strategi berupa skenario pembelajaran yang mempertimbangan waktu pelaksanaan penelitian, kemampuan siswa dalam menangkap materi, dan keluasan dari materi pembelajaran itu sendiri; 3) Pelaksanaan Tindakan: Guru peneliti melaksanakan pembelajaran dengan mengikuti strategi dan prosedur sesuai perencanaan tindakan yang telah disusun sebelumnya; 4) Observasi Kelas: Observer dan guru peneliti melakukan pengamatan kegiatan baik guru maupun siswa yang berlangsung selama proses belajar mengajar. Pengamatan ini dilakukan sesuai dengan format lembar observasi yang telah disepakati oleh guru peneliti dengan observer saat perencanaan tindakan dan 5) Refleksi: Guru peneliti bersama observer menganalisis hasil pengamatan dari proses belajar mengajar dikelas secara bersama sama. Selanjutnya didiskusikan apa saja kelebihan dan kekurangan dalam pelaksanaan tindakan kelas untuk selanjutnya dijadikan evaluasi dan bahan rencana tindakan selanjutnya.

Indikator keberhasilan pada pelaksanaan penelitian tindakan kelas ini, yaitu 1) Adanya kesesuaian antara urutan penyajian materi dengan alokasi waktu penelitian dan perencanaan tindakan dan 2) Adanya peningkatan hasil belajar siswa yang dilihat dari nilai tes tiap siklusnya.

\section{HASIL PENELITIAN DAN PEMBAHASAN Hasil Siklus I}

Siklus I merupakan tahap penyesuaian terhadap materi dan media pembelajaran agar siswa dapat mencapai tujuan pembelajaran yang sesuai dengan Rencana Pelaksanaan Pembelajaran. Siklus I juga merupakan tahap observasi guru untuk menyesuaikan media pembelajaran untuk siswa. Pada siklus I diketahui: (1) Guru belum dapat mengalokasikan waktu dengan baik, hal ini terlihat dengan waktu pembelajaran melebihi waktu yang telah direncanakan sebelumnya; (2) Guru masih harus menjelaskan materi saat siswa tidak mengerti; (3) Sebagian siswa masih ribut sehingga siswa lain tidak bisa konsentrasi dalam mencermati video. Dari hasil observasi ini dilakukan refleksi antara lain: (1) Guru akan memperbaiki kesesuaian waktu dengan rencana terutama pada saat pemutaran video; (2) Guru tetap memperhatikan keberjalanan kelas sehingga apabila siswa tidak mengerti, guru dapat menjelaskannya; (3) Guru mengkondisikan siswa terlebih dahulu sebelum pemutaran video.

\section{Siklus II}

Siklus II merupakan siklus lanjutan dengan memperhatikan rencana tindak lanjut yang telah dibuat pada siklus I. Pada siklus ini didapatkan : (1) Guru sudah dapat mengalokasikan waktu dengan baik, karena guru sudah mengkondisikan siswa terlebih dahulu; (2) Guru memberikan tugas merangkum setelah pemutaran video tentang strategi Dakwah Rasulullah saw periode Madinah, sehingga siswa dapat lebih konsentrasi dalam kegiatan pembelajaran.

Peningkatan hasil belajar siswa pada penelitian ini diukur dari nilai tes formatif.

Tabel 2. Hasil Belajar Siswa

\begin{tabular}{ccc}
\hline Rata Rata & Siklus I & Siklus II \\
\hline Test Siklus & 72,82 & 78,04 \\
\hline & 13 & 19 \\
\cline { 2 - 3 } JumlahTuntas & $56.52 \%$ & $82.61 \%$ \\
\hline
\end{tabular}




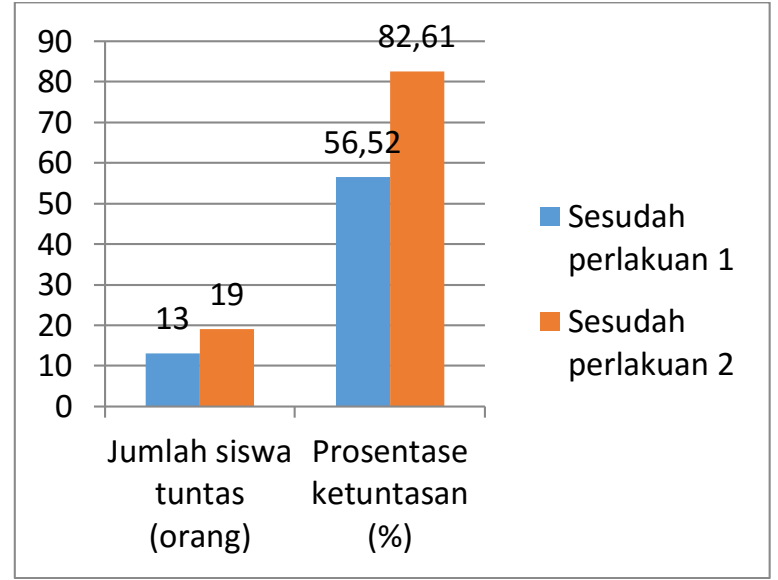

\section{Diagram 1. Prosentase ketuntasan nilai siswa}

Dari tabel dan diagram di atas dapat kita lihat kenaikan prosentase yang sangat signifikan pada siklus I dan siklus II. Bahwa jumlah siswa yang tuntas pada siklus I adalah 13 orang dan mengalami kenaikan pada siklus II sebanyak 19 orang dari total jumlah siswa 23 orang.

$\underline{\text { Tabel 3. Keaktifan Siswa Dalam Pembelajaran }}$

\begin{tabular}{cccc}
\hline Rata Rata & $\begin{array}{l}\text { Sebelum } \\
\text { Perlakuan }\end{array}$ & Siklus I & Siklus II \\
\hline Siswa & 1,75 & & \\
Aktif & & 2,75 & 3,17 \\
\hline
\end{tabular}

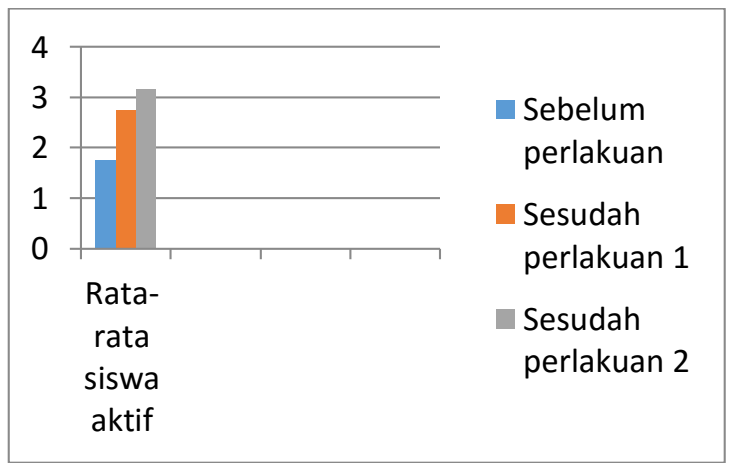

Diagram 2. Grafik Keaktifan Siswa

Dari tabel dan diagram hasil observasi keaktifan siswa di atas dapat disimpulkan bahwa siswa lebih respon terhadap pembelajaran menggunakan media video dibandingkan dengan tidak menggunakan media dalam kegiatan pembelajaran.

Peran media video sangat penting dalam kehidupan sehari-hari, karena dapat memberikan informasi yang lebih canggih dan cepat. Video selain memberikan informasi dan hiburan juga dapat dijadikan sebagai media pembelajaran. Tujuannya adalah agar proses pembelajaran akan lebih cepat ditangkap dan dipahami oleh peserta didik. Selain itu juga para pengajar atau guru akan lebih mudah menyampaikan materi melalui media video. Tentunya hal tersebut harus didukung oleh ilmu pengetauan dan pengusaan teknologi terhadap materi yang diajarkan.

Pengaruh media video akan lebih cepat masuk ke dalam diri manusia daripada media yang lainnya. Karena penayangannya berupa cahaya titik fokus, sehingga dapat mempengaruhi fikiran dan emosi manusia. Dalam kegiatan belajar mengajar, fokus dan mempengaruhi emosi dan psikologi anak didik sangat diperlukan. Karena dengan hal tersebut peserta didik akan lebih mudah memehami pelajarannya. Tentunya media video yang disampaikan kepada anak didik harus bersangkutan dengan tujuan pemebelajaran.

Penyampaian materi melalui media video dalam pembelajaran bukan hanya sekedar menyampaikan materi sesuai dengan kurikulum. Akan tetapi ada hal lain yang perlu diperhatikan yang dapat mempengaruhi minat peserta didik dalam belajar. Hal tersebut berupa pengalaman atau situasi lingkungan sekitar, kemudian dibawakan ke dalam materi pelajaran yang disampaikan melalui video. Selain itu juga dalam pelajaran peraktek peserta didik akan lebih mudah melakukan apa yang dilihatnya dalam video daripada materi yang disampaikan melalui buku atau gambar. Kegiatan seperti ini akan memudahkan peserta didik dan guru dalam proses belajar mengajar.

Ada banyak kelebihan video ketika digunakan sebagai media pembelajaran di antaranya menurut Nugent (dalam Smaldino, 2008: 310 ) video merupakan media yang cocok untuk berbagai ilmu pembelajaran, seperti kelas, kelompok kecil, bahkan satu siswa seorang diri sekalipun.

Hal itu, tidak dapat dilepaskan dari kondisi para siswa saat ini yang tumbuh berkembang dalam dekapan budaya televisi, di mana paling tidak setiap 30 menit menayangkan program yang berbeda. Dari itu, video dengan durasi yang hanya beberapa menit mampu memberikan keluwesan lebih bagi guru dan dapat mengarahkan pembelajaran secara langsung pada kebutuhan siswa. 


\section{SIMPULAN DAN SARAN Simpulan}

Berdasarkan hasil yang didapatkan pada penelitian tindakan kelas ini dapat ditarik kesimpulan bahwa 1) Hasil belajar siswa kelas XF SMK SMTI Pontianak dengan penggunaan media video pada materi Strategi dakwah Rasulullah saw. periode Madinah meningkat. Hal ini dapat dilihat dari tabel nilai tes siswa tiap siklus dan jumlah siswa yang tuntas. Rata rata kelas naik dari 70 menjadi 72.82 dan jumlah siswa tuntas naik dari $56.52 \%$ menjadi $82.61 \%$ pada siklus I dan II; dan 2) Respon siswa kelas XF SMK SMTI Pontianak dengan penggunaan media video saat kegiatan pembelajaran sangat baik, dapat dilihat dari hasil observasi keaktifan siswa.

\section{Saran}

Berdasarkan temuan penelitian dan pemahaman yang telah penulis lakukan dalam bab-bab sebelumnya, maka saran kedepannya 1) Penggunaan video dalam kegiatan pembelajaran bisa menjadi salah satu referensi media pembelajaran untuk meningkatkan hasil belajar siswa; dan 2) Diharapkan guru dapat lebih kreatif dan inovatif dalam mengembangkan media pembelajaran ini.

\section{DAFTAR RUJUKAN}

Ahmadi, Abu dan Widodo Supriyono.1991. A.M. Sardiman. (2003). Interaksi dan Motivasi Belajar Mengajar. Jakarta: PT. Raja Grafindo Persada.

Clark. (1981). Tersedia pada http://www.sarjanaku.com/2011/03/pengertia n-definisi-hasil-belajar.html.
Depdikbud. (1995). Kamus Besar Bahasa Indonesia. Jakarta: Balai Pustaka.

Halimah, Iim dkk. (2014). Pendidikan Agama dan Budi Pekerti. Jakarta: Erlangga.

Hamalik, Oemar. (2005). Perencanaan Pengajaran Berdasarkan Pendekatan Sistem. Jakarta: PT. Bumi Aksara.

Haryono, (2015). Bimbingan Teknik Menulis Penelitian Tindakan Kelas (PTK). Yogyakarta: Amara Books.

Ibrahim, R dan Nana Syaodih. (2003). Perencanaan Pengajaran. Jakarta: Rineka Cipta.

Sanjaya, Wina. (2011). Model Pembelajaran Berorientasi Standar Proses Pendidikan. Jakarta: Kencana.

Kustandi, Cecep dan Bambang Sutjipto. (2011). Media Pembelajaran Manual dan Digital. Bogor: Ghalia Indonesia.

Mansur, Ahmad. (2011). Metode Penelitian dan Teknik Penulisan Laporan Karya Ilmiah. Bandung: PAAP FEB-UNPAD.

Nana Sudjana. (1989). CBSA: Cara Belajar Siswa Aktif dalam Proses Belajar. Mengajar. Bandung: Sinar Bara Algesindo

Smaldino, E. Sharon dkk. (2008). Instructional Technology and media for learning. Upper Saddle River, New Jersey Columbus, Ohio. Ninth Edition.

Sofyan, Ahmad. (2006). Evaluasi Pembelajaran Berbasis Kompetensi. Jakarta: UIN Jakarta

Sudjana, Nana. (2000). Dasar-dasar Belajar Mengajar. Bandung: Tarsito

Sudjana, Nana. (2004). Dasar-dasar Proses Belajar Mengajar. Bandung: Sinar Baru Algensido Offset.

Susilana, Rudi dan Cepi Riyana. (2008). Media Pembelajaran. Bandung: CV.Wacana 